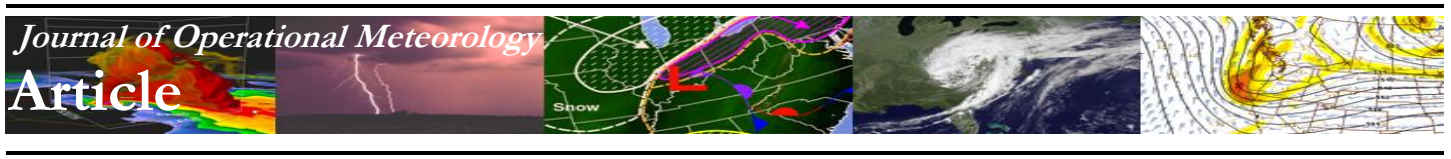

\title{
The Epic Eastern North American Warm Episode of March 2012
}

\author{
RICHARD GRUMM \\ National Weather Service, State College, Pennsylvania \\ JUSTIN M. ARNOTT \\ National Weather Service, Gaylord, Michigan \\ JEFFREY HALBLAUB \\ National Weather Service, Hastings, Nebraska
}

(Manuscript received 29 July 2013; review completed 22 January 2014)

\begin{abstract}
A historic warm episode occurred over much of eastern North America in March 2012, resulting in the warmest March on record over the contiguous United States. The impact of this warm episode on fruit crops in the Midwest was substantial, as early blossoming followed by an April freeze resulted in the loss of over 90\% of some crops. Additionally, the ridge responsible for the warm episode also resulted in a pattern favorable for flooding and severe weather across the southeastern United States.

This event was characterized by an anomalous ridge over eastern North America, with standardized anomalies suggesting that $500-\mathrm{hPa}$ heights and $850-\mathrm{hPa}$ temperatures were as high as has been documented in the past $30 \mathrm{yr}$. Although standard teleconnection indices were not significant during this event, a connection to the phase of the Madden-Julian Oscillation is shown. From a standardized anomaly approach, this event also was found to be very predictable by deterministic and ensemble guidance at lead times of up to 10 days. The breadth and persistence of positive height and temperature anomalies provided increased confidence in this record-setting event.
\end{abstract}

\section{Introduction}

Heat waves are well documented in meteorological literature (Church 1913; Cramer and Lynott 1970; Namias 1982; Chang and Wallace 1987; Brugge 1995; Robinson 2001) and are a leading cause of weather-related deaths (Changnon et al. 1996; Goklany 2009). The following have been used as definitions of a heat wave:

- a period where the maximum temperature exceeds normal by $5^{\circ} \mathrm{C}$ or more for five consecutive days (Met Office 2014);

- a "period of abnormally and uncomfortably hot and usually humid weather" (Glickman 2000); and

- a 48-h period where the daytime (nighttime) maximum (minimum) heat index exceeds (does not fall below) $105^{\circ} \mathrm{F}\left(80^{\circ} \mathrm{F}\right)$ (Robinson 2001).
These and other studies have raised awareness that strong midlevel ridges (in particular subtropical ridges) typically play a significant role in these events. In addition to anomalous warmth, large ridges are often associated with strong meridional moisture transport on their western flanks. For example, Grumm (2011, their Fig. 4d) showed that the ridge associated with the 2010 Russian heat wave transported deep moisture into central and northern Europe. Over North America, the location and strength of the ridge can modulate moisture transport associated with the lowlevel jet typical of the Great Plains (Weaver and Nigam 2008). The enhanced meridional flow helps produce a "ring-of-fire" effect, resulting in enhanced rainfall and convection around the periphery of the ridge. These northward surges of deep moisture on the western periphery of the ridge are often termed "moisture plumes," which, in some cases, may qualify as atmospheric rivers (Neiman et al. 2008). These also

Corresponding author address: Justin M. Arnott, 8800 Passenheim Road, Gaylord, MI 49735

E-mail: justin.arnott@noaa.gov 
can be a key component in providing moisture for many heavy rainfall events. To the east of this poleward moisture surge, there are many instances of prolonged heat waves occurring with drought (Chang and Wallace 1987; Lyon and Dole 1995).

Less documented are heat waves that occur outside of the summer months (hereafter termed "warm episodes"). McQueen and Pope (1957) investigated a warm episode in April 1957 that persisted for over one week. Given the occurrence of this event in the spring, the effects of the warm episode were confined primarily to farming interests (because of precipitation modulation), with an additional impact being the occurrence of forest fires due to extreme dryness in New England. Although other studies document warm episodes outside of the summer months (e.g., Nunn 1927; Wagner 1976; Livezey 1981), their primary aim was to describe the meteorological aspects of the events, rather than the impacts or predictability.

A historic warm episode occurred during March 2012. For the northeastern United States, Great Lakes, and Ohio Valley regions, this was the warmest March on record (Fig. 1a), with many locations seeing average maximum temperature anomalies of over $8^{\circ} \mathrm{C}$ $\left(15^{\circ} \mathrm{F}\right)$ (Fig. 1b). During this warm episode, 7755 daily record maximum temperatures were tied or broken across the United States [National Climatic Data Center (NCDC; 2012a)], along with 7517 daily record high-minimum temperatures. These represent over $4 \%$ of the total possible United States temperature records for the month (Fig. 2). The ridge responsible for the anomalous warmth reached peak intensity during the period of 13-23 March when five days recorded over $500(\sim 10 \%)$ daily maximum temperature records, peaking at 710 on 20 March. The impacts of the anomalous warmth continued through the spring, as early blooming of fruit crops and a return to normal temperatures in April resulted in substantial fruit crop losses due to frost/freezing conditions.

There are two primary goals of this study. The first is to document the March 2012 warm episode and place it in meteorological and historical context through the use of standardized anomalies (e.g., Hart and Grumm 2001). This will allow an increased understanding as to what caused the event, as well as its meteorological and horticultural impacts (section 3 ). The second goal is to examine the predictability of this event using tools available to the operational forecaster (section 4). The impacts of these events can be better mitigated, not only with more accurate

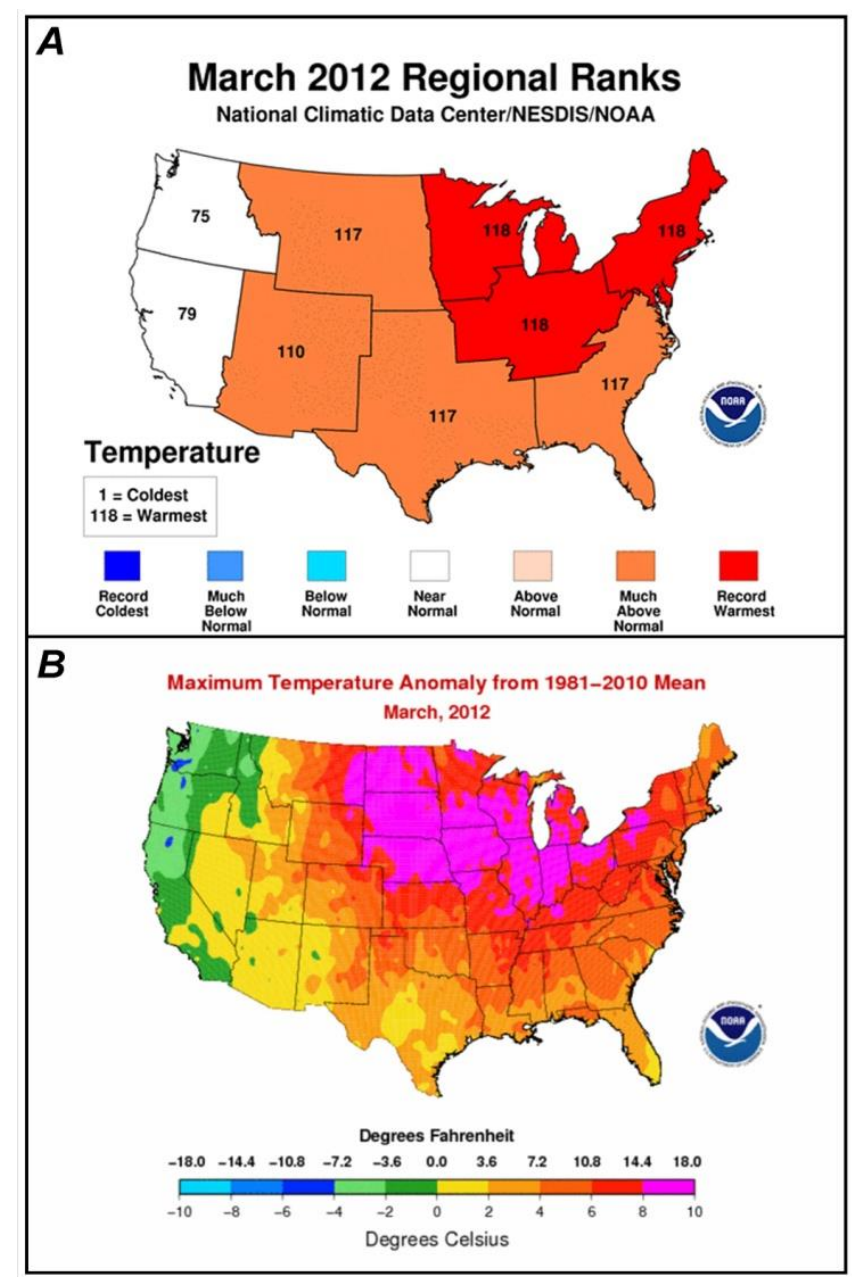

Figure 1. United States regional rankings of a) March 2012 temperatures and b) average maximum temperature anomalies for March 2012. Images from the NCDC. Click image for an external version; this applies to all figures hereafter.

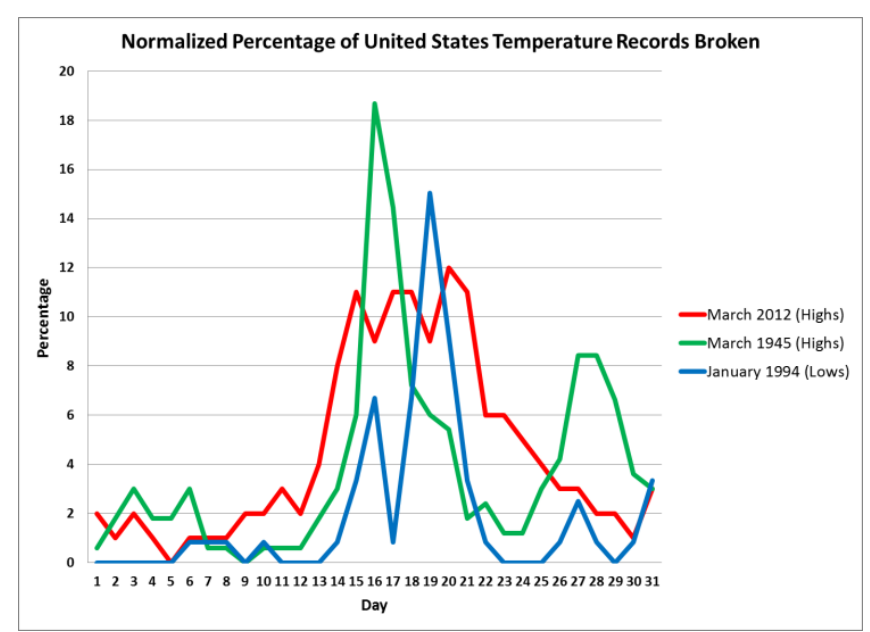

Figure 2. Percentage of United States temperature records broken in March 2012 (red line), March 1945 (green line), and January 1994 (blue line). Data have been normalized for the changing period of record length, using a stationary climate assumption. 
forecasts, but also with forecasts that provide forecaster confidence information to the user at various lead times.

\section{Data and methods}

Temperature record data from the NCDC (2012a), including the Applied Climate Information System (DeGaetano et al. 2010), were used to examine March 2012 and other prolonged periods of extreme temperature anomalies in the eastern United States. Model analyses (i.e., 0-h forecasts available at a grid spacing of $27.5 \mathrm{~km}$ ) from the National Centers for Environmental Prediction (NCEP) Global Forecast System (GFS) were used to represent the large-scale conditions associated with the event. The standardized anomalies are displayed in standard deviations $(\sigma)$ from normal (Hart and Grumm 2001) and are computed using the climatology from the $2.5 \times 2.5$ degree NCEP/National Center for Atmospheric Research (NCEP/NCAR) global reanalysis data (Kalnay et al. 1996). Standardized anomalies were used by Hart and Grumm (2001) to show the historical significance of weather events (relative to climatology) and to anticipate their potential significance. The reader is referred to that study for a discussion on how these anomalies were calculated.

To examine the historical rarity of the standardized anomalies observed during this event, a 33-yr climatology of these values was created using the 32$\mathrm{km}$ North American Regional Reanalysis (NARR). Standardized anomalies were computed every $6 \mathrm{~h}$ for the 33-yr period and were examined to find the largest anomalies. Comparative images for other anomalous events during the past century were created using the 20th Century Reanalysis (Compo et al. 2011).

The value of ensemble forecast systems (EFSs) and standardized anomalies with EFS data also is presented. Ensemble data shown are from the NCEP Global EFS (GEFS), which was run at $55-\mathrm{km}$ horizontal grid spacing. Based on Grumm (2011) and Lipton et al. (2005), the data analysis is focused on 500-hPa heights, $700-\mathrm{hPa}$ temperatures, $850-\mathrm{hPa}$ temperatures, precipitable water (PW), and the forecast standardized anomalies of these fields (again compared to the NCEP/NCAR global reanalysis). The focus on these fields is based on their ability to clearly define the large-scale pattern and the association of strong ridges and above-normal $850-$ and $700-\mathrm{hPa}$ temperatures with heat waves. Forecasters frequently make use of $850-\mathrm{hPa}$ temperatures when forecasting surface temperatures, given the relationship between these two values under dry-adiabatic (i.e., well-mixed) scenarios - typical during large-scale ridging.

Note that both the GFS analyses and GEFS forecasts are shown at a resolution that is finer than the NCEP/NCAR reanalysis dataset used as the model climate. As described in Grumm (2011), the impact of this difference is small for synoptic-scale features, being most noticeable for standardized anomaly computations of PW where values would be higher than if a similar (i.e., larger) grid spacing was used.

Data used in the analysis were obtained from multiple sources. Most of the data used were obtained and then archived locally in real-time from NCEP. Longer-range GEFS data (>144 h) for 9 and 10 March 2012 were retrieved from the European Centers for Environmental Prediction's THORPEX (The Observing-System Research and Predictability Experiment) Interactive Grand Global Ensemble (TIGGE) portal (tigge.ucar.edu/home/home.htm). The GEFS data obtained from the TIGGE site were in 6-h increments. NCEP Stage IV precipitation analyses (Lin and Mitchell 2005) were used to examine the precipitation distribution during this event, as described in section 3 .

In addition to the single analysis and forecast products, geographic-relative composites were used because showing individual dates and times would be prohibitive since this event persisted for over 10 days. Additionally, persistent events require the use of compositing techniques to forecast and characterize the event. Composites of the model analyses (i.e., 0-h forecasts) were used to show the pattern over a specified time range using all intervening 6-h GFS analyses. Composites of the model forecasts also used all intervening 6-h forecasts of the GEFS.

\section{Overview of the March 2012 warm episode}

\section{a. Characterization using standardized anomalies}

Standardized anomalies were used to gain insight into the large-scale features that contributed to the anomalous warm episode. Figure 3 shows the breadth and magnitude of ridging that encompassed most of eastern North America during the 13-23 March 2012 period. The occurrence of +2 to $+3 \sigma$ anomalies is impressive, given the fact that this figure represents an 11-day average. In addition to the height and temperature fields, Fig. 3 also shows similar anomaly values for PW. Note the expansive area of positive 

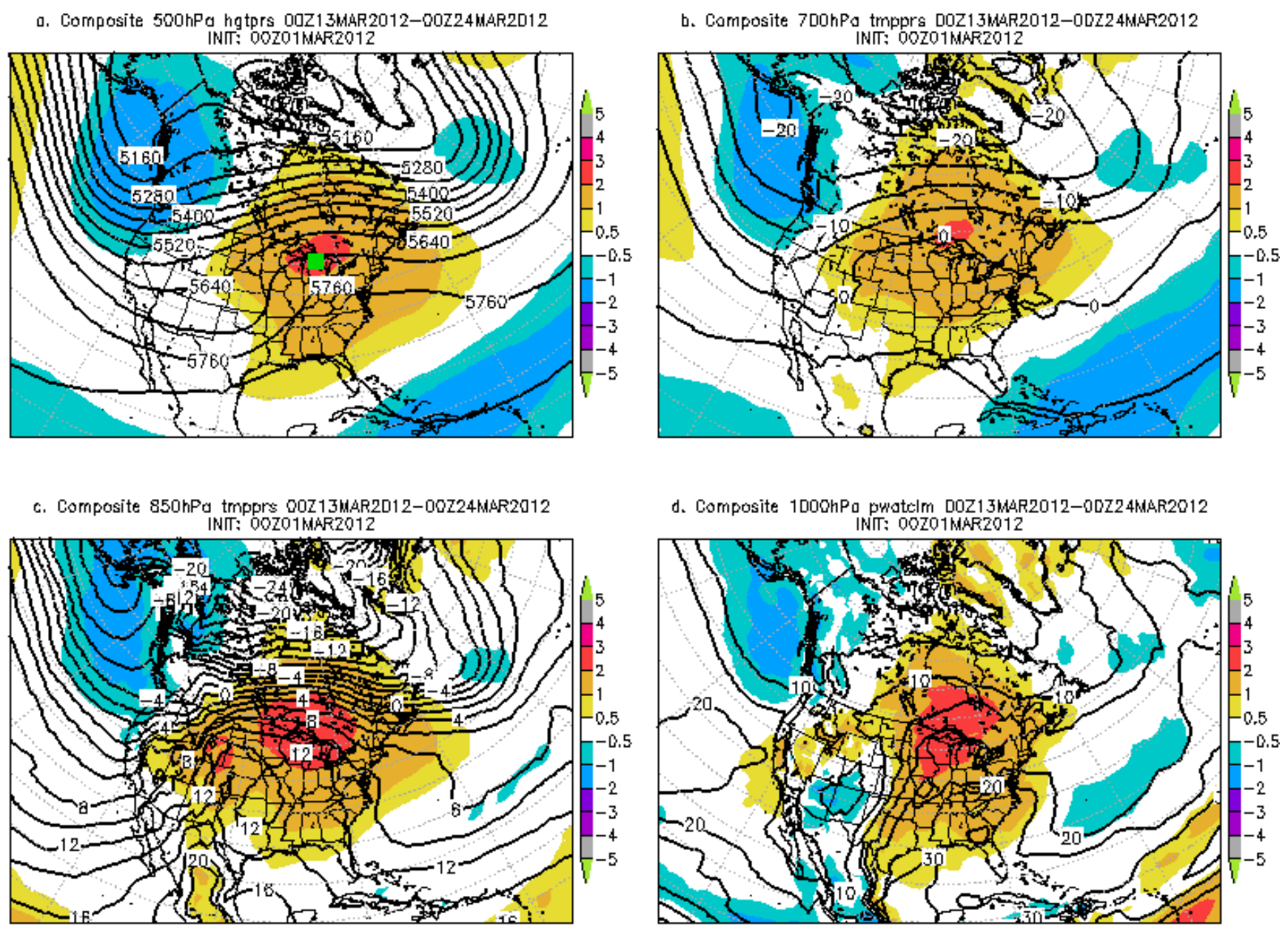

Figure 3. The mean pattern and standardized anomalies for the period from 0000 UTC 13 March to 0000 UTC 24 March 2012 from GFS 0-h forecasts. Data include a) 500-hPa heights (m) and standardized anomalies, b) 700-hPa temperatures $\left({ }^{\circ} \mathrm{C}\right)$ and standardized anomalies, c) 850 -hPa temperatures $\left({ }^{\circ} \mathrm{C}\right)$ and standardized anomalies, and d) precipitable water $(\mathrm{mm})$ and standardized anomalies. The 500 -hPa heights are contoured every $60 \mathrm{~m}, 700$-hPa temperatures every $5^{\circ} \mathrm{C}, 850$-hPa temperatures every $2^{\circ} \mathrm{C}$, and precipitable water every $5 \mathrm{~mm}$. Standardized anomaly values are shaded per the color bar to the right of each image. The green square in a) is near Alpena, MI.

anomalies streaming north from the Gulf of Mexico along the Mississippi Valley and into central Canada. This provided ample moisture for the flooding rains (see section 3c) observed along the western edge of the anomalous ridging, where capping produced by largescale subsidence would be weaker.

To examine the daily evolution of features during this warm episode, the $850-\mathrm{hPa}$ temperatures valid at 0000 UTC 18-23 March 2012 (Fig. 4) are shown. The warmest $850-\mathrm{hPa}$ temperatures and largest anomalies were focused initially in the western Plains and north of the Great Lakes (Figs. 4a-b). The warm air gradually moved eastward, and a weak cut-off low (not shown) with relatively cool air moved out of the southern Plains toward the Missouri Valley (Figs. 4df). Although this feature would reduce the number of high temperature records tied or broken as it moved eastward (recall Fig. 2), the persistence of anomalous warmth to its east is striking.

\section{b. External forcing and teleconnection patterns}

Forecasters frequently examine teleconnection indices and forecasts of these indices to develop expectations of the large-scale pattern at mid- and upper-levels of the atmosphere, which can be used to infer details about temperature anomalies and precipitation placement. During the 11-day warm episode, the Pacific North American (PNA; Wallace and Gutzler 1981) and North Atlantic Oscillation (NAO; Wallace and Gutzler 1981) teleconnection patterns were near zero or slightly positive (not 


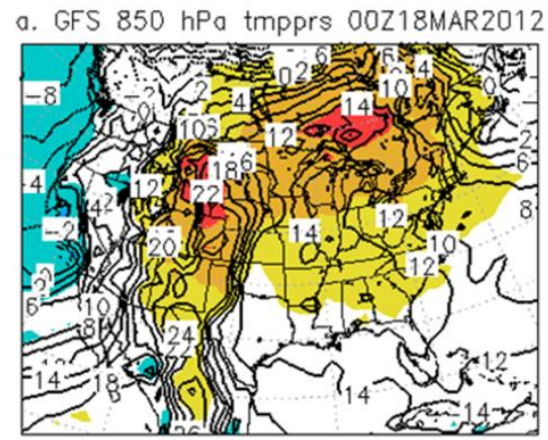

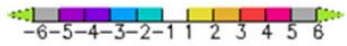
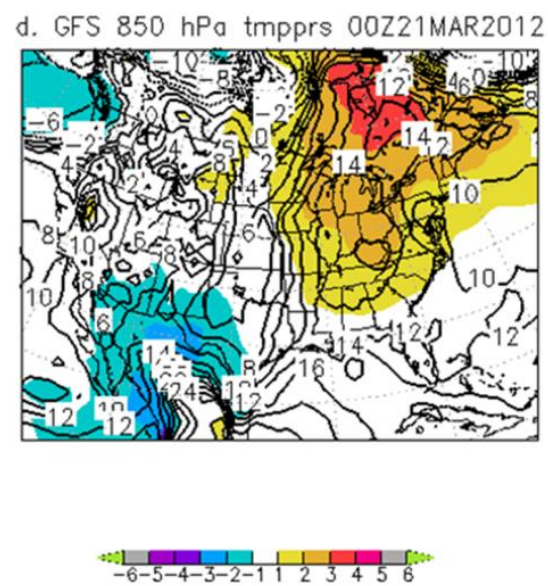
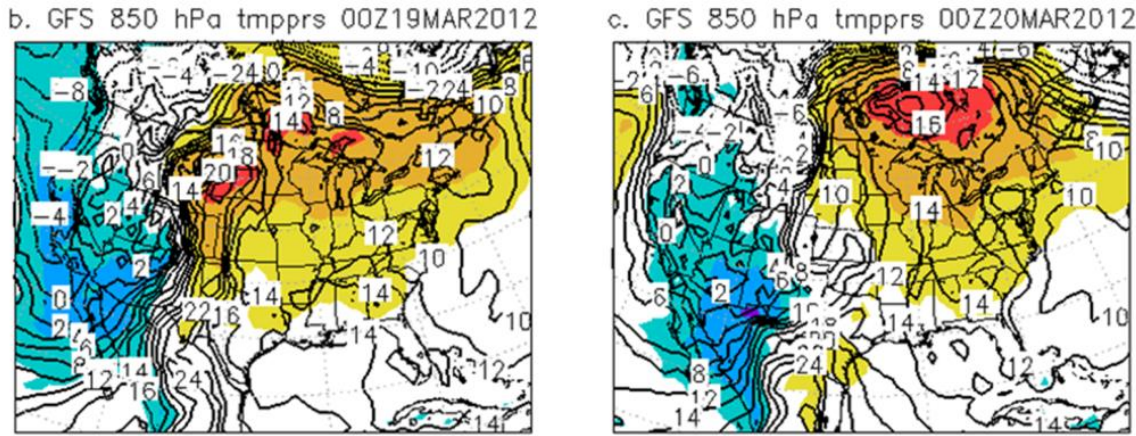

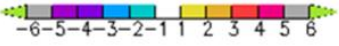
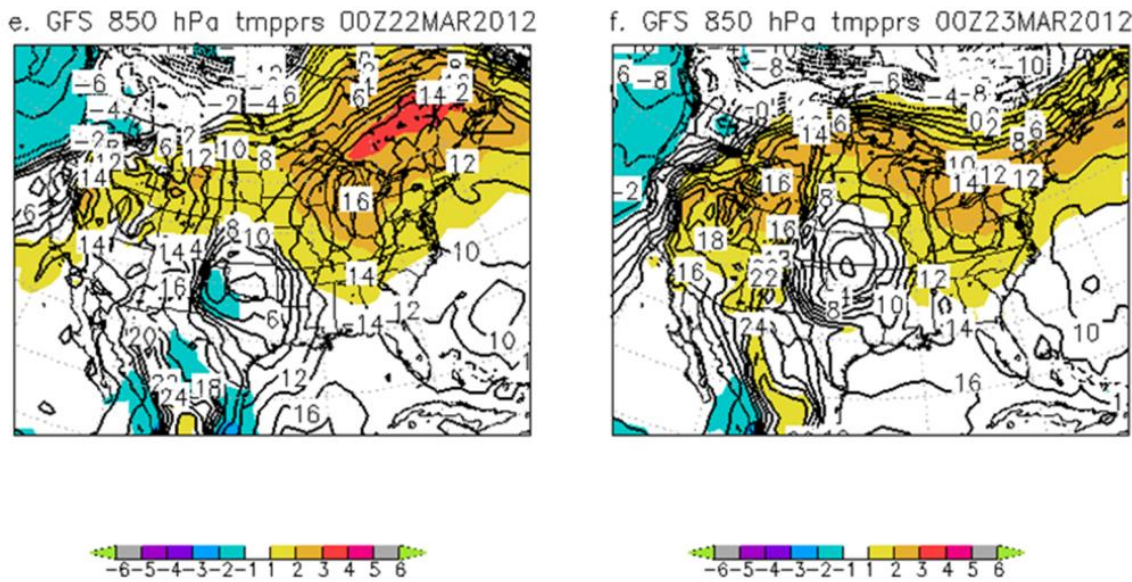

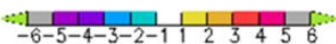

Figure 4. GFS 0-h forecasts of 850-hPa temperatures and standardized anomalies in 24-h increments from 0000 UTC 18 March (a) through 23 March 2012 (f). Temperature contours every $2^{\circ} \mathrm{C}$, and standardized anomaly values are shaded and displayed per the color bar below each image.

shown). A positive (negative) PNA pattern typically is associated with below (above) normal heights in the eastern United States (Wallace and Gutzler 1981), and the negative (positive) NAO typically is associated with relatively cold (warm) air in northeastern North America. Given the degree of amplification to the large-scale pattern shown in Fig. 3, this lack of a signal in the NAO and PNA suggests that the loading patterns for these indices did not align with the largescale pattern in March 2012 and, therefore, should not be used in isolation when anticipating anomalous temperatures.

In addition to the NAO and PNA, the MaddenJulian Oscillation (MJO; Madden and Julian 1971, 1972) has gained increasing use as a tool in long-range forecasting; convection over the equatorial Pacific can have a significant connection to thickness anomalies (and therefore temperatures) across the eastern United
States (Kousky 1985). This is because of a relationship between the convection and a northward shift in the polar jet stream between November and March (Mo and Higgins 1998a,b). Wheeler and Hendon (2004), expanding the original work of Madden and Julian (1971, 1972), developed a real-time, multivariate MJO index consisting of eight phases. Each phase depicts the location of enhanced and suppressed convection in its eastward advancement from the Indian Ocean into the Pacific Ocean.

During March 2012, the MJO progressed from phase 3 to phase 7 (Fig. 5) and, during the warm episode, from phase 5 to phase 7. Zhou et al. (2011) constructed temperature anomaly composites for the various phases of the MJO index (available on the NCEP website at www.cpc.ncep.noaa.gov/products/ precip/CWlink/MJO/Composites/Temperature/). Temperature composites for the three-month period of 
(RMM1,RMM2) for 1-Dec-2011 to 31-Mar-2012

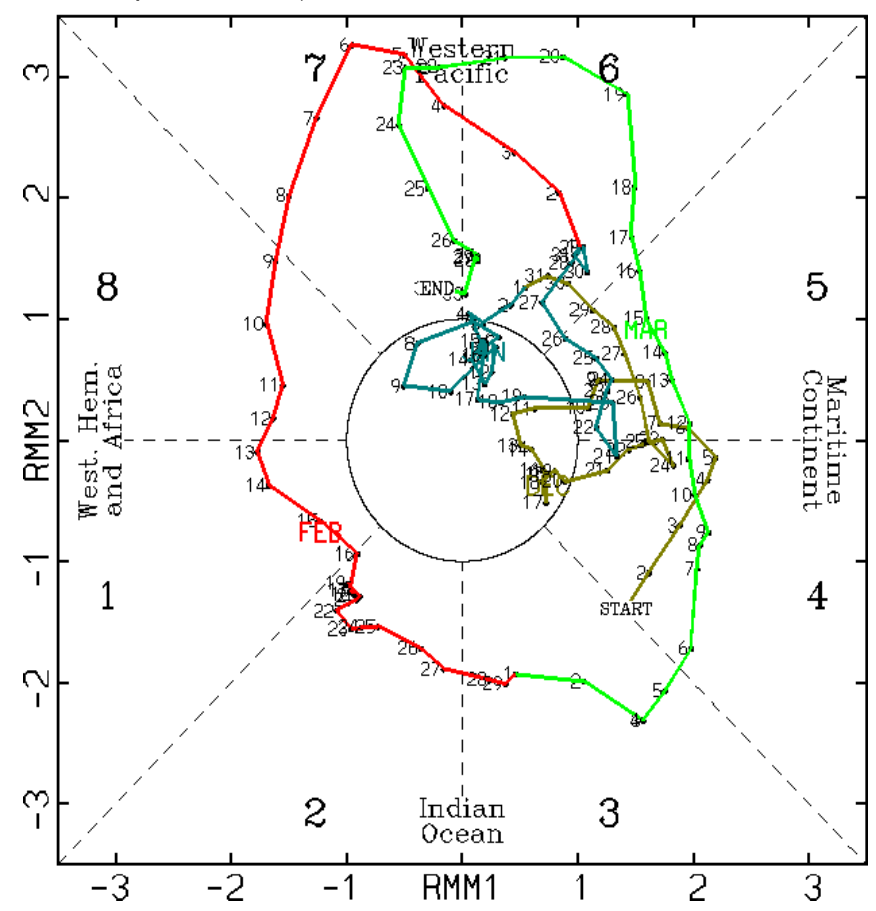

Figure 5. Wheeler diagram highlighting the MJO phase during the December 2011-March 2012 period. Numbers along the line indicate the date, with line color indicating month. The March portion of the line is shown in green. Image obtained from NCEP.

January-March show that, during phases 4 through 7 , warmer than normal temperature anomalies are typical over the eastern United States. The positive anomalies are maximized during phase 6 at the 95\% confidence level and coincide with the heart of the warm episode of 17-21 March. The above analysis suggests that the March warm episode was related more strongly to the phase of the MJO than to the NAO and PNA teleconnection indices.

\section{c. Impacts}

Early season warm episodes rarely have a large human impact because of the overall lower average temperatures compared to summer. The horticultural impacts, however, can be substantial. Throughout much of the upper Midwest, the March warmth led to a sufficient accumulation of growing degree days that broke the dormancy of blossoms on many fruit trees and plants by early April. With multiple subsequent intrusions of polar air into the region during April, many nights of sub-freezing temperatures occurred. This resulted in significant crop losses as the blossoms were either damaged or destroyed. Some examples include:
- crop losses of over $\$ 200$ million in the state of Michigan (Flesher 2012);

- over $90 \%$ loss of the tart cherry crop and apple crop in Michigan (Flesher 2012; Ramde and Antlfinger 2012); and

- horticultural disaster areas declared in Michigan (Flesher 2012).

a. Accumulated liquid equivalent precipitation $(\mathrm{mm})$ from 18Z01MARZ012 to 18Z31MAR2012
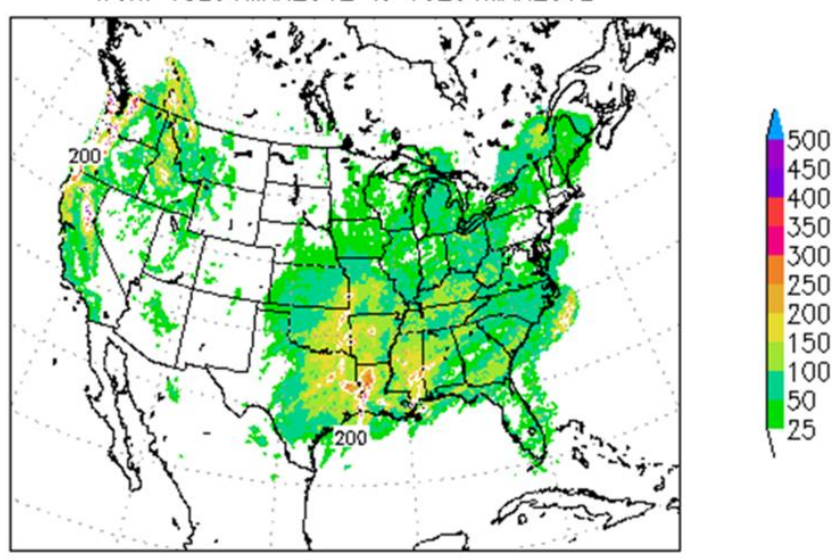

b. Accumulated liquid equivalent precipitation (mm) from 12Z14MARZO12 to 12Z22MAR2012
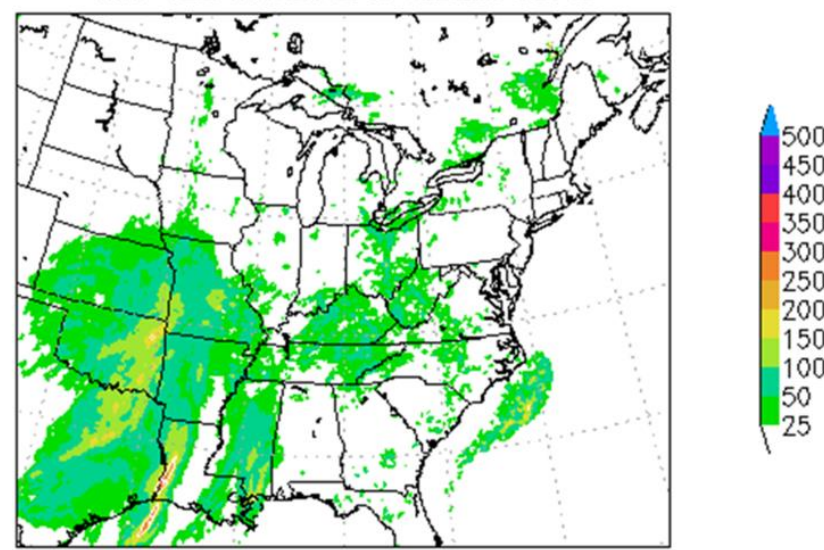

Figure 6. NCEP stage-IV total rainfall (mm, color bar at right) over the central and eastern United States for the periods of a) 1800 UTC 1 March-1800 UTC 31 March 2012 and b) 1200 UTC 14 March-1200 UTC 22 March 2012.

The location and persistence of the midtropospheric ridge responsible for the March warmth greatly modulated precipitation placement. Rainfall was focused in a north-south band from the Gulf of Mexico into the central Plains from 14 to 22 March (Fig. 6b). This was located on the western flank of the strong subtropical ridge (see section 3a) responsible for the warm episode. The heaviest rainfall, in excess 
a. Composite 500hPo hat O0Z15MAR1945-18Z31MAR1945

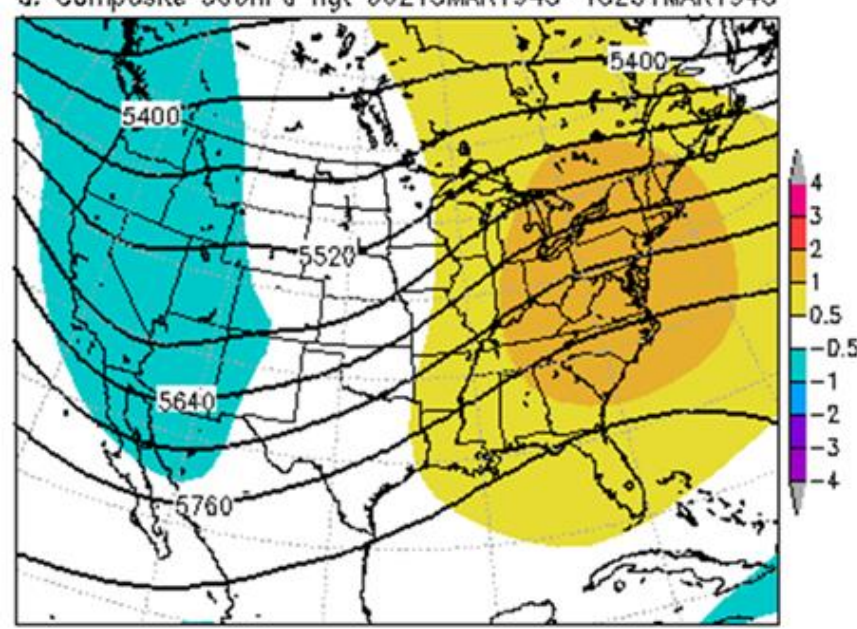

c. Composite $850 \mathrm{hPo}$ oir O0Z15MAR1945-18Z31MAR1945

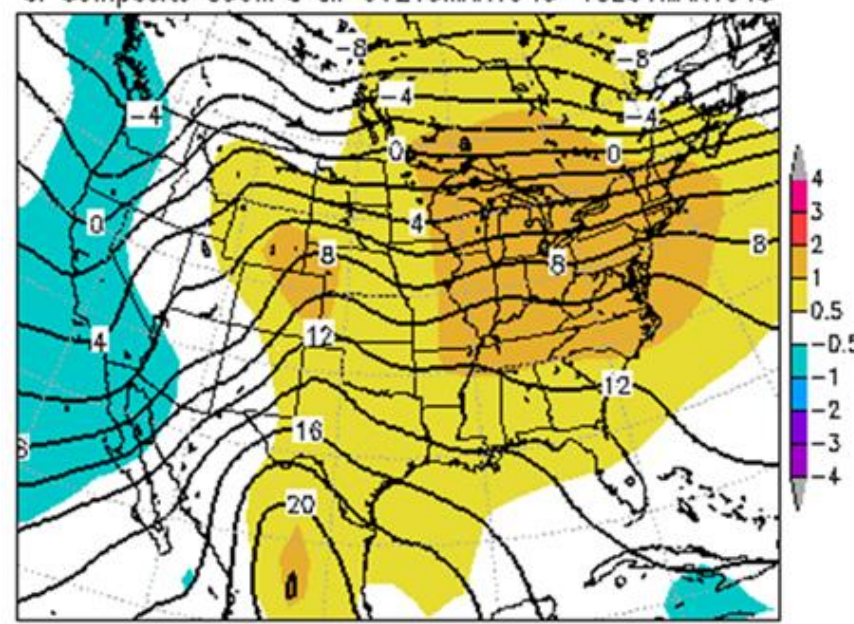

b. Composite $700 \mathrm{hPo}$ dir OOZ15MAR1945-18Z31MAR1945

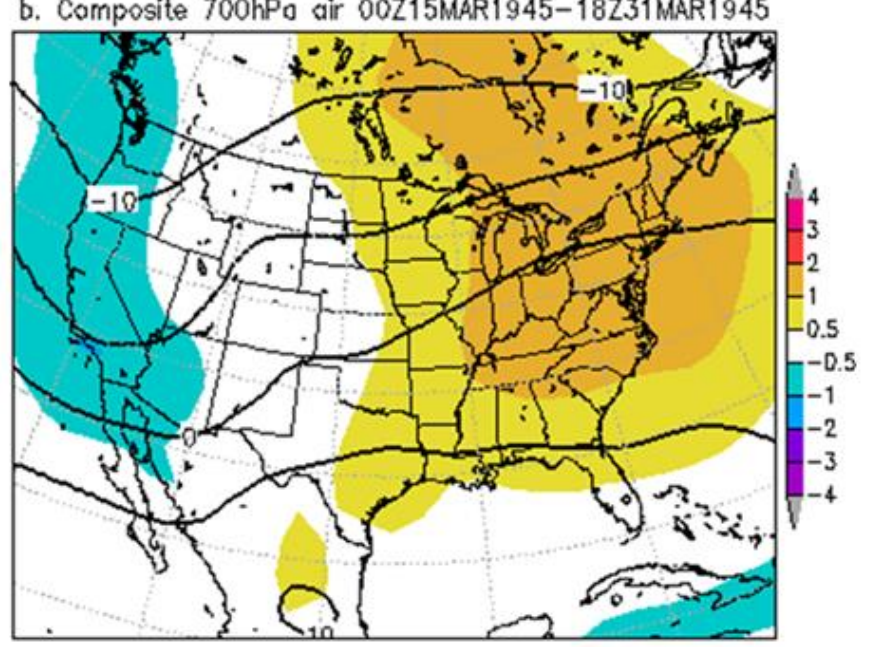

d. Composite 1000hPo pr_wtr OOZ15MAR1945-18Z31MAR 1945

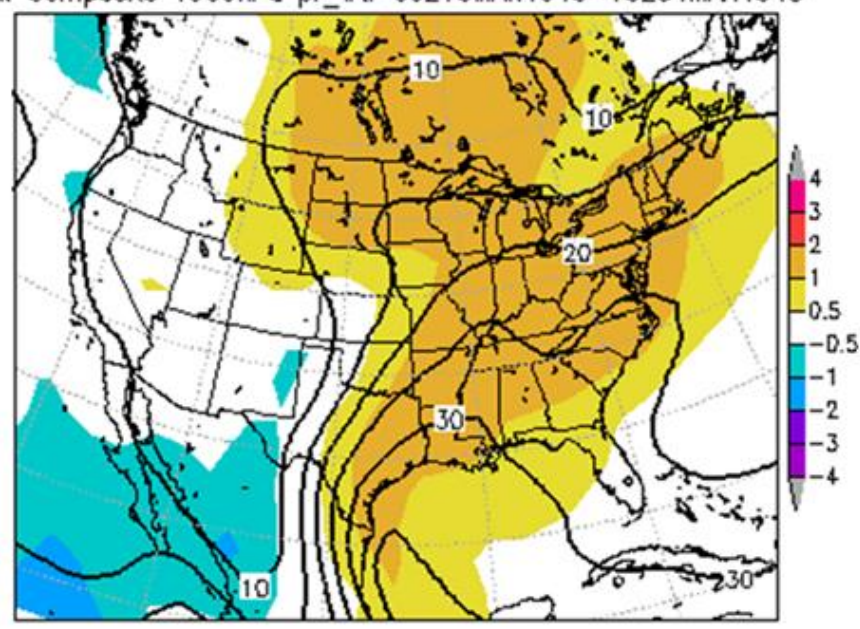

Figure 7. As in Fig. 3 but for the composite pattern from 0000 UTC 15 March through 1800 UTC 31 March 1945.

of $250 \mathrm{~mm}$, was focused over the Gulf states. This rainfall resulted in flash flooding across Louisiana, Mississippi, and Alabama (NCDC 2012b). In addition to heavy rainfall, the tropical moisture plume also supported severe weather, as most of the organized severe weather reports were noted west of the ridge (not shown). Further east under the ridge, note the relative dryness (Fig. 6b) over the eastern United States. This large-scale view clearly shows that the ridge associated with the warm episode played a significant role in the distribution of precipitation across the eastern two-thirds of the country.

\section{d. Historical comparison}

An examination of individual station data revealed that March 1945 was the warmest March prior to 2012 for many locations in the Great Lakes and midAtlantic regions. In March 1945, 4080 record high temperatures were tied or broken across the United States (NCDC 2012a, Fig. 2). When normalizing these temperature records for the changing period of record and included stations, this represents a very similar percentage (4\%) when compared to March 2012 $(4.5 \%)$.

Comparing the composites for March 1945 and 2012 (Figs. 7 and 3) shows that similar large-scale patterns occurred. A persistent ridge was present over the East Coast with anomalously warm 700- and 850$\mathrm{hPa}$ temperatures, although the anomalies were somewhat lower than experienced in 2012. Similar to March 2012, and heat waves in general, the PW field shows a surge of high-PW air from the Gulf into the central United States on the western flank of the strong ridge. The Palmer Z- and Palmer Drought Severity indices (Palmer 1965; Karl 1986) - measures of shortand long-term moisture anomalies, respectively- 
indicate anomalously wet conditions occurred from eastern Texas into Ohio and dry conditions occurred along the East Coast during March of 1945 (not shown). Although shifted somewhat east, this pattern of precipitation distribution is quite similar to that seen in March 2012 (Fig. 6a).

Table 1. Ten largest standardized anomaly values from the NARR at Alpena, MI, for $500-\mathrm{hPa}$ heights (top, in $\mathrm{m}$ ) and $850-\mathrm{hPa}$ temperatures (bottom, in ${ }^{\circ} \mathrm{C}$ ) for the period 1979-2012. Rows in bold indicate times during the 2012 March warm episode.

\begin{tabular}{|c|c|c|c|}
\hline \multicolumn{4}{|c|}{ Alpena, MI, March 500-hPa Heights } \\
\hline Rank & Time and Date & Height (m) & $\sigma$ \\
\hline 1 & 1200 UTC 21 March 2012 & 5803 & 2.87 \\
\hline 2 & 1800 UTC 21 March 2012 & 5805 & 2.86 \\
\hline 3 & 0600 UTC 21 March 2012 & 5804 & 2.86 \\
\hline 4 & 0000 UTC 22 March 2012 & 5801 & 2.83 \\
\hline 5 & 0000 UTC 21 March 2012 & 5796 & 2.80 \\
\hline 6 & 0600 UTC 22 March 2012 & 5794 & 2.76 \\
\hline 7 & 1800 UTC 14 March 1995 & 5775 & 2.75 \\
\hline 8 & 1200 UTC 14 March 1995 & 5771 & 2.73 \\
\hline 9 & 0600 UTC 14 March 1995 & 5771 & 2.71 \\
\hline 10 & 1800 UTC 13 March 1995 & 5768 & 2.71 \\
\hline \multicolumn{4}{|c|}{ Alpena, MI, March 850-hPa Temperatures } \\
\hline Rank & Time and Date & Temp. $\left({ }^{\circ} \mathrm{C}\right)$ & $\sigma$ \\
\hline 1 & 0000 UTC 22 March 2012 & 16.2 & 2.94 \\
\hline 2 & 1800 UTC 07 March 1987 & 14.5 & 2.91 \\
\hline 3 & 1800 UTC 13 March 2007 & 14.9 & 2.88 \\
\hline 4 & 1200 UTC 21 March 2012 & 15.2 & 2.83 \\
\hline 5 & 1800 UTC 21 March 2012 & 15.3 & 2.82 \\
\hline 6 & 0600 UTC 21 March 2012 & 15.0 & 2.78 \\
\hline 7 & 0600 UTC 22 March 2012 & 15.0 & 2.77 \\
\hline 8 & 0600 UTC 16 March 2003 & 14.5 & 2.77 \\
\hline 9 & 0000 UTC 18 March 2012 & 14.2 & 2.73 \\
\hline 10 & 0000 UTC 15 March 2012 & 13.9 & 2.72 \\
\hline
\end{tabular}

The large-scale pattern shown in Fig. 3 certainly would be expected to produce anomalous warmth over much of the eastern United States, but some historical context is necessary to determine the rarity of this pattern. In Table 1 , the 10 largest standardized anomalies for NARR 500-hPa heights and $850-\mathrm{hPa}$ temperatures during March are listed for Alpena, Michigan. This shows that the anomalies seen in Fig. 3 are among the largest in the last $30 \mathrm{yr}$, with a value of $+3 \sigma$ not observed in this historical record. Interestingly, if we examine these anomalies in the context of all months from 1979 to 2012 (Fig. 8), the values for March are even more impressive, being above the 99th percentile for both $850-\mathrm{hPa}$ temperatures and $500-\mathrm{hPa}$ heights. From these results and simple hydrostatic arguments, this large-scale pattern led to
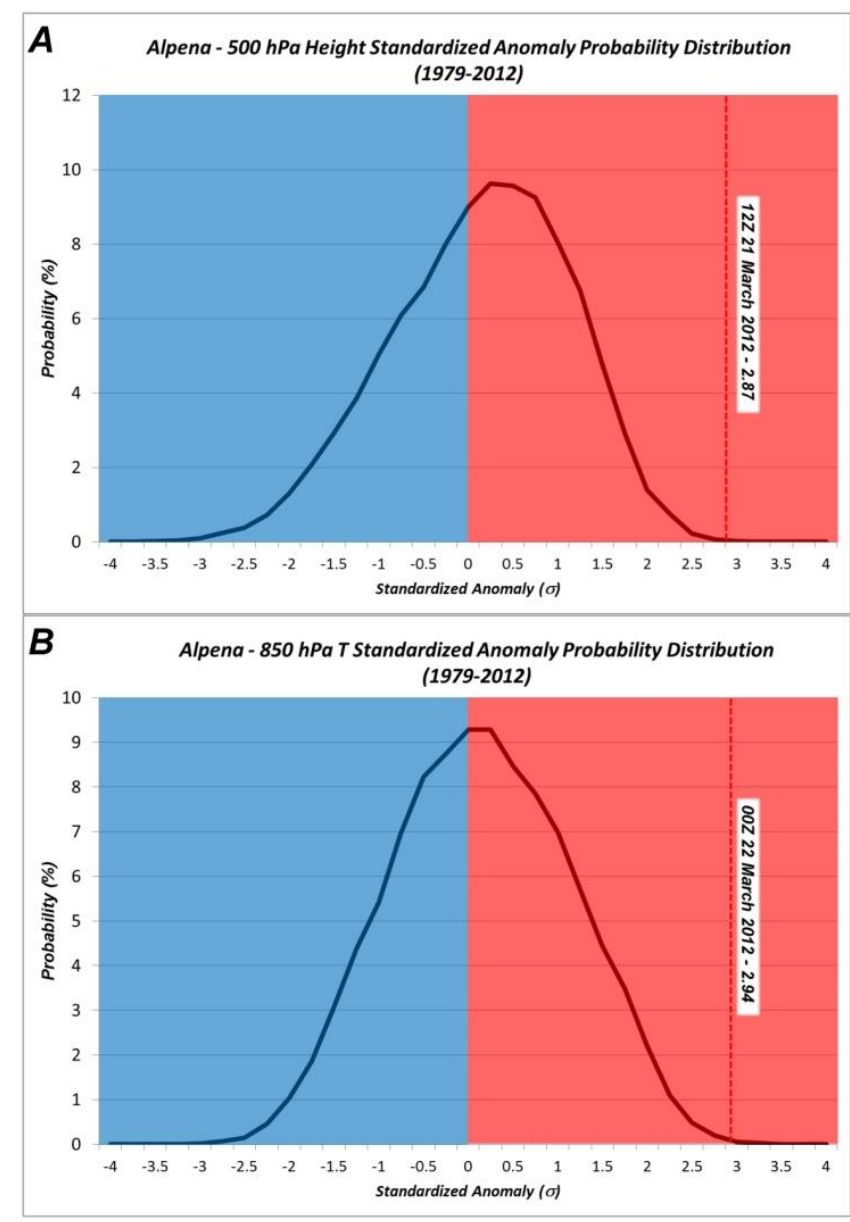

Figure 8. Frequency distribution of standardized anomalies at Alpena, MI, for a) 500-hPa heights and b) $850-\mathrm{hPa}$ temperatures based on 6-h 1979-2012 NARR data. In each diagram, the peak value during the March warm episode is highlighted by the red dashed line.

unprecedented warmth at many locations in the northeastern United States.

\section{Predictability}

Given how anomalous this event was, as well as its numerous impacts highlighted in section 3, an examination of the event's predictability is warranted to understand better how far in advance this event could be anticipated by forecasters, and then communicated to decision-makers. Anomaly correlations frequently are computed to assess numerical weather model performance for large-scale fields (e.g., Tracton et al. 1989; Palmer et al. 1990). For March 2012, 5-day 500-hPa height anomaly correlations (not shown) from frequently used global models [i.e., GFS, European Centre for Medium Range Weather Forecasts (ECMWF), and United Kingdom Meteor- 


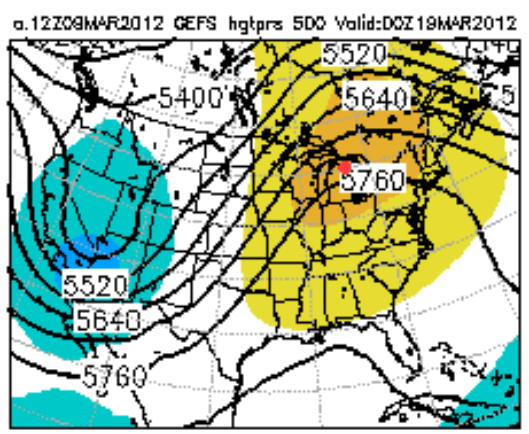

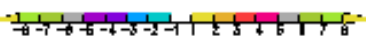

d. $12712 \mathrm{k}$ F 2012 GeFs hgtpre 500 Yalid:DOZ 19k4R2012

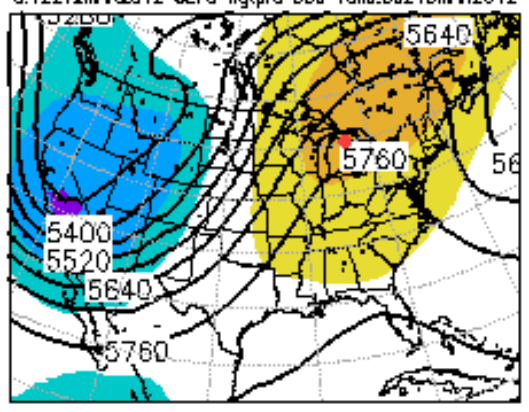

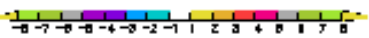

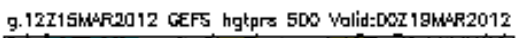

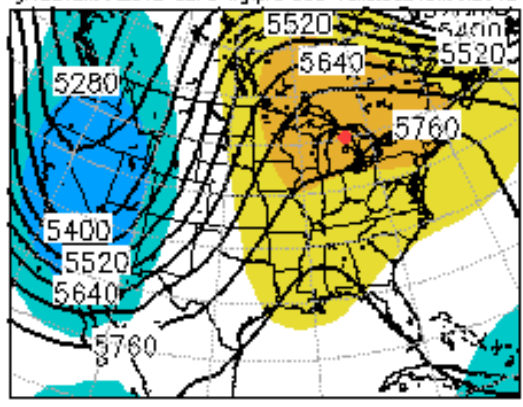

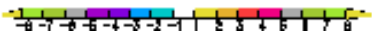

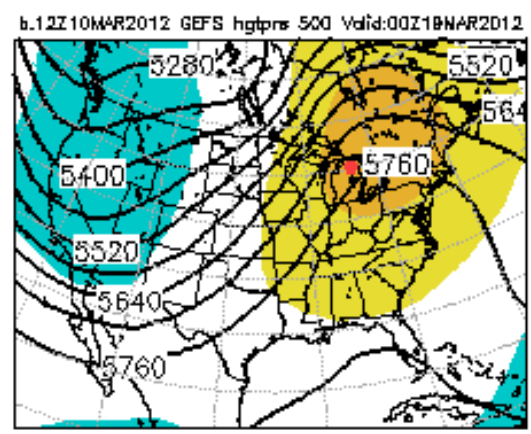

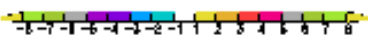

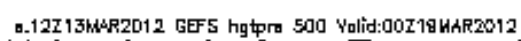

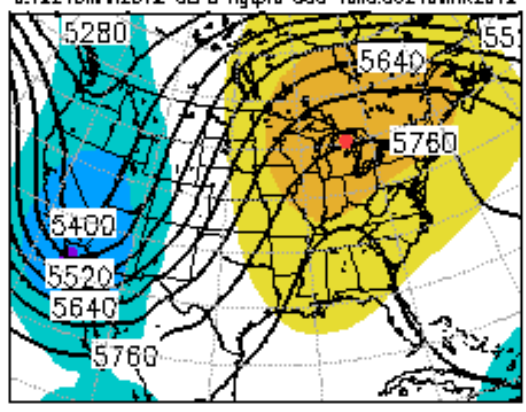

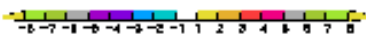

h.12T16WAR2012 Gers hgtro 5S0 Vdid:000Z19HAR2012

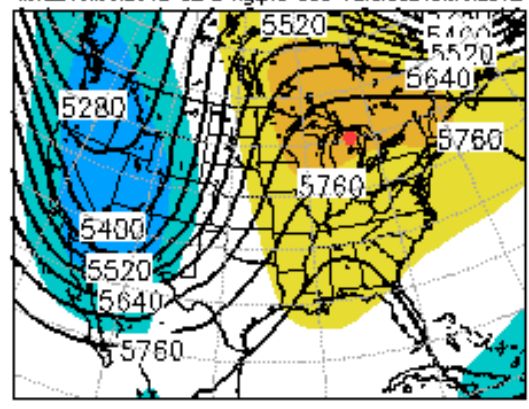

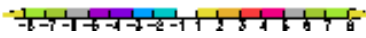

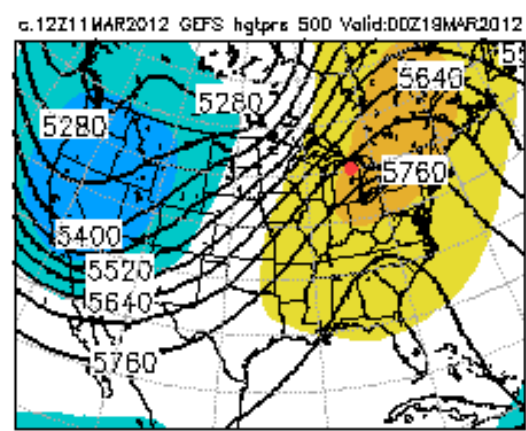

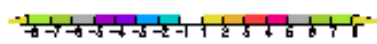

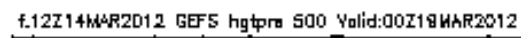

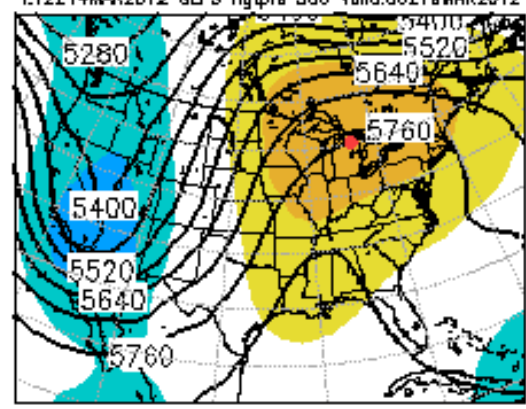

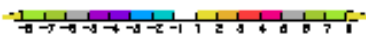

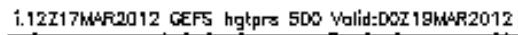

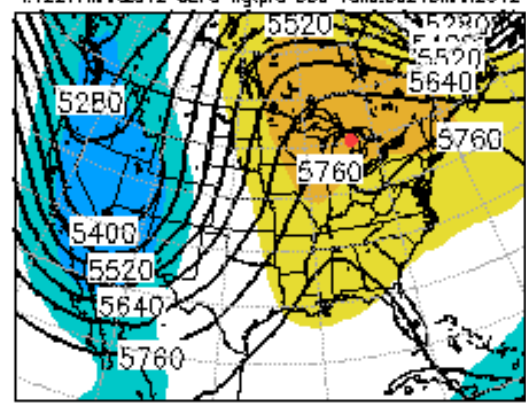

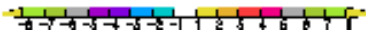

Figure 9. NCEP GEFS forecasts of 500-hPa heights (m) and standardized anomalies over the United States valid at 0000 UTC 19 March 2012 from forecasts initialized at (a) 1200 UTC 9 March to (i) 17 March 2012. Standardized anomalies are shaded per the color bar below each image.

ological Agency (UKMET)] were similar to those in 2011 and did not show an increase or decrease in skill during this event. With values close to 0.9 (a perfect score is 1.0), this anomalous event did not produce a degradation in forecast skill.

Forecasts of 500-hPa heights, 850-hPa temperatures, and associated standardized anomalies from nine successive GEFS runs valid at 0000 UTC 19 March (Figs. 9 and 10) show the consistent predictions of the 500-hPa ridge and accompanying anomalous 850-hPa temperatures over eastern North America. A comparison of Fig. 10 with Fig $4 \mathrm{~b}$ also reveals that the 850-hPa temperature forecasts were quite accurate, with similar results for 500-hPa heights (not shown). These forecasts are significant because of how con- sistently the GEFS predicted the overall $500-\mathrm{hPa}$ and $850-\mathrm{hPa}$ patterns over eastern North America and how widespread the above-normal 500-hPa height and 850$\mathrm{hPa}$ temperature anomalies were. The large standardized anomalies in these forecasts provide a measure of confidence (e.g., Stuart et al. 2013). In order for large anomalies to occur, each ensemble member must have a similar forecast over a particular geographic area. Viewing subsequent forecasts using standardized anomalies for this event shows that, although some of the details changed from run to run in the GEFS (Figs. 9 and 10), the overall pattern of anomalous ridging and warmth was very consistent, which adds confidence to the forecast. This increased confidence could have been relayed to decision makers at advanced lead 


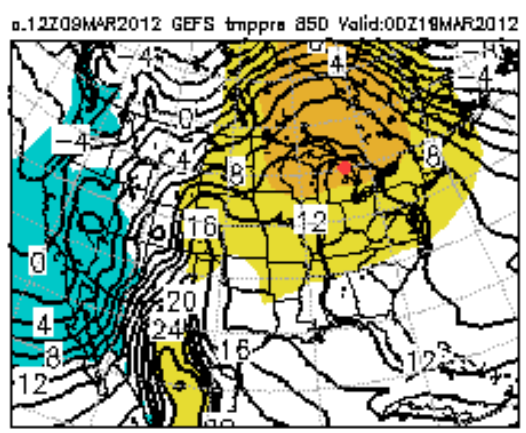

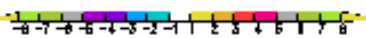

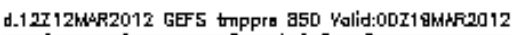

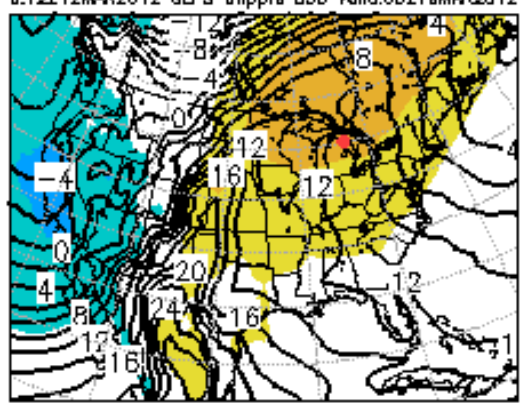

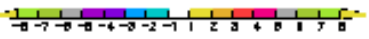

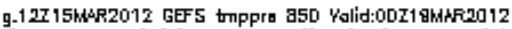

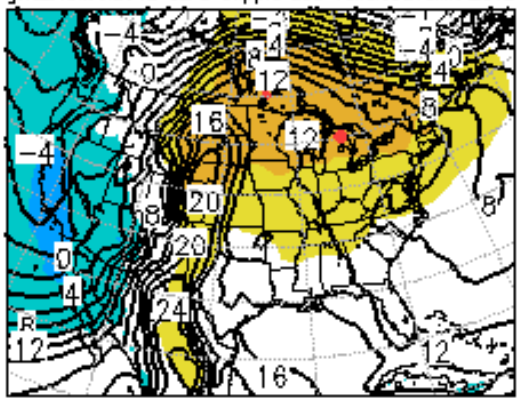

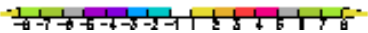

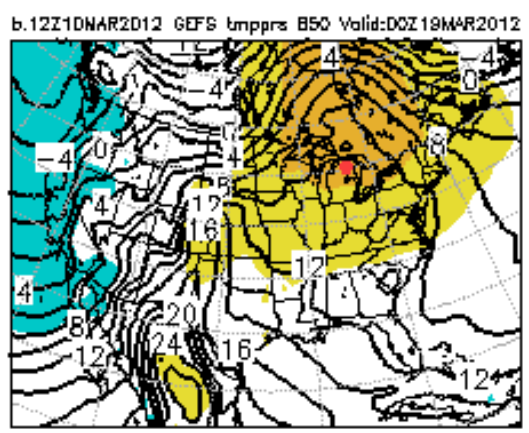

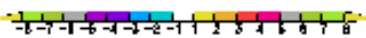

0.12Z13HAR2012 GerS tmppre BSO Valid:WOL 19k4R2012

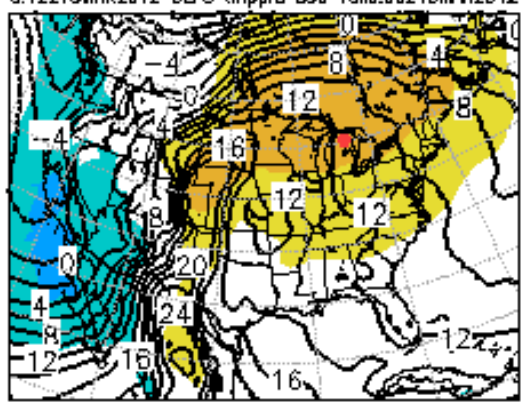

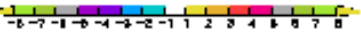

h.12I16NAR2012 Gers tmpprs 850 Valid:COL19W'R2012

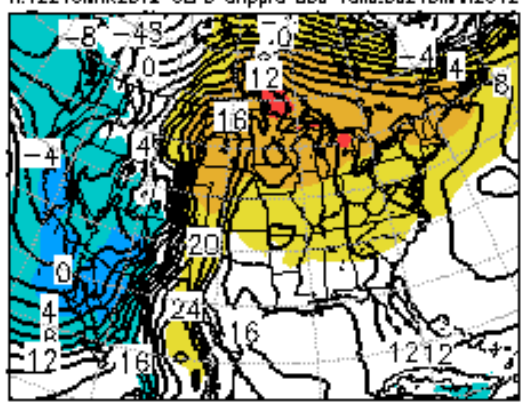

-1

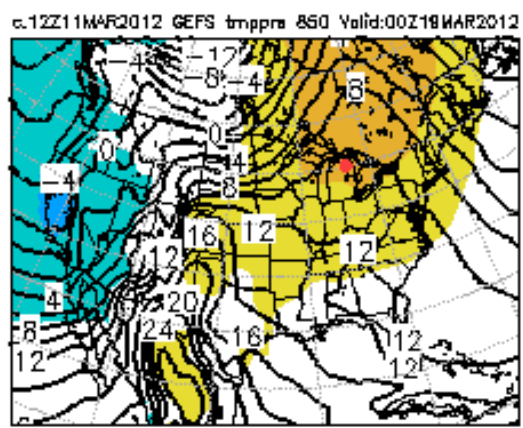

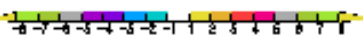

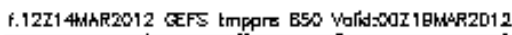

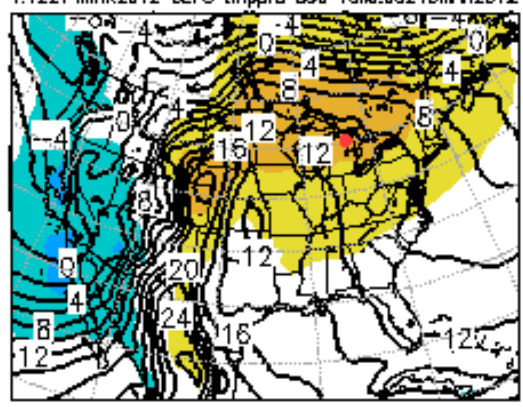

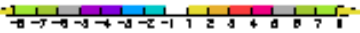

i.12Z17WAR2012 GeFs tmppro a50 Yolid:00Z19kkR2012

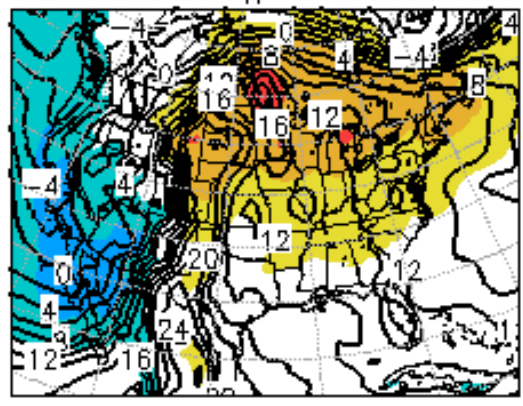

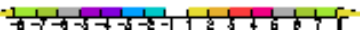

Figure 10. As in Fig. 9 except for GEFS 850-hPa temperatures $\left({ }^{\circ} \mathrm{C}\right)$.

times, helping further to mitigate potential impacts from the upcoming event. Though not shown, the ECMWF and GFS portrayed a similar and consistent pattern.

The composite mean GEFS forecast from 1200 UTC 10 March for the period valid 0000 UTC 14 March through 0000 UTC 20 March is shown in Fig. 11. Despite averaging 21 ensemble forecasts at each 6$\mathrm{h}$ forecast interval for six days, the pattern revealed average standardized anomalies on the order of +2 to $+3 \sigma$ for $500-\mathrm{hPa}$ heights, $700-\mathrm{hPa}$ temperatures, and 850-hPa temperatures. The $\mathrm{PW}$ anomalies showed a broad region of +2 to $+3 \sigma$ and a region of +3 to $+4 \sigma$ near James Bay. Though not shown, these values were slightly lower than those from similar forecasts from the GFS over the same time interval, implying at least some contribution of uncertainty in the forecasts.
Shorter duration composites for the 48-h forecast period during the maximum extent of record-high temperatures from the 1200 UTC 10 March (Fig. 12) and 1200 UTC 17 March (not shown) simulations show the same general pattern and slightly sharper features relative to the 6-day composite (Fig. 11). During the 48-h period from 0000 UTC 18 March through 0000 UTC $20 \mathrm{March}$, the 8-10-day forecast showed areas of +4 to near $+5 \sigma$ PW anomalies and, though not shown, the deterministic GFS had $+5 \sigma$ PW anomalies at this time. There were notable differences in the forecasts, especially over the Dakotas, Montana, and Colorado, where slightly increased amplification in the observed flow-pattern aloft, versus what was forecast, resulted in the warmth associated with the ridge existing further west than originally forecast. 

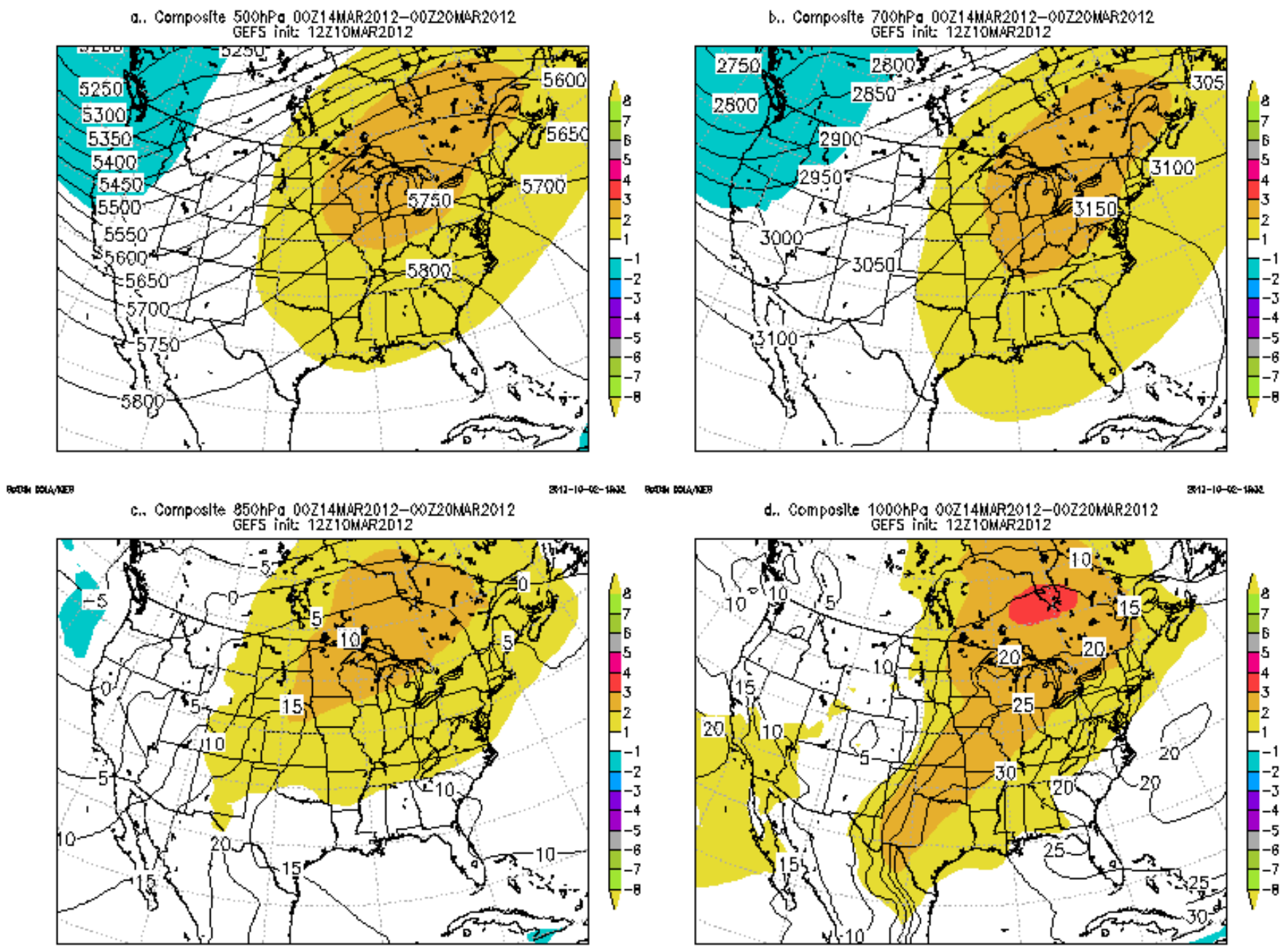

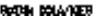

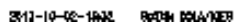

sat-10-4e-1ax

Figure 11. NCEP GEFS forecasts initialized at 1200 UTC 10 March 2012 with the composite mean forecast for the period from 0000 UTC 14 March to 0000 UTC 20 March 2012 and showing the a) mean 500-hPa heights (m) and standardized anomalies, b) mean 700-hPa heights (m) and standardized anomalies, c) mean 850-hPa temperatures $\left({ }^{\circ} \mathrm{C}\right)$ and standardized anomalies, and d) mean total precipitable water $(\mathrm{mm})$ and standardized anomalies. Standardized anomalies are shaded per the color bar to the right of each image.

\section{Summary and discussion}

The March 2012 warm episode broke thousands of temperature records, led to flooding rains, resulted in severe weather, and had a dramatic negative impact on horticulture in the months following the event. Additionally, the mid- and upper-level height patterns responsible for the warm episode persisted to a lesser extent through much of the following summer. With higher than typical evapotranspiration rates in March owing to the anomalous warmth, soil moisture was prematurely reduced during the spring. These factors combined to produce a significant drought across much of the central United States. Daily anomalies of thermodynamic fields were impressive, but even more impressive was the breadth of these anomalies, as well as their persistence. Although the standardized anomalies characterizing the anomalous $500-\mathrm{hPa}$ heights and $850-\mathrm{hPa}$ temperatures associated with the eastern North American ridge were less than $+3 \sigma$, they still were among the highest values over the past $30 \mathrm{yr}$. This shows the importance of using frequency distributions when examining the rarity of standardized anomalies.

Interestingly, if we apply these concepts to an event of the opposite sign, we can see similar utility using a well-known Arctic outbreak that occurred across the eastern United States in January 1994 (Walsh et al. 2001). For the month, 3844 daily record low temperatures were tied or broken across the United States (NCDC 2012a), with 2999 of them 
a. Composite 500hPa 00Z16máR2012-00Z20kér:2012

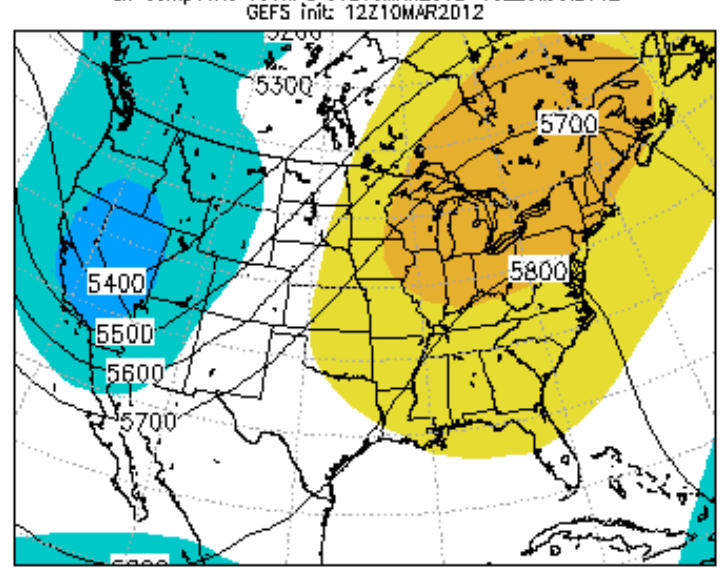

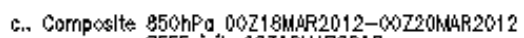

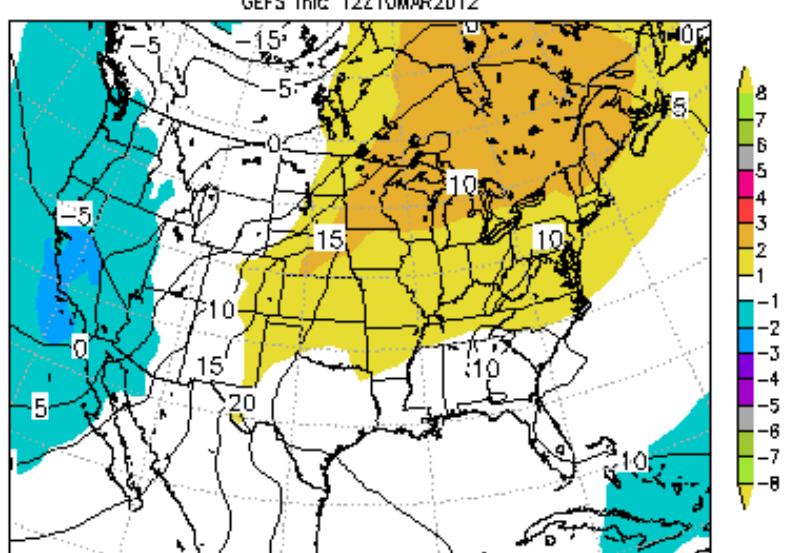

b. Composite 700hPo 00Z1 BdAR2012-00Z20kerR2012

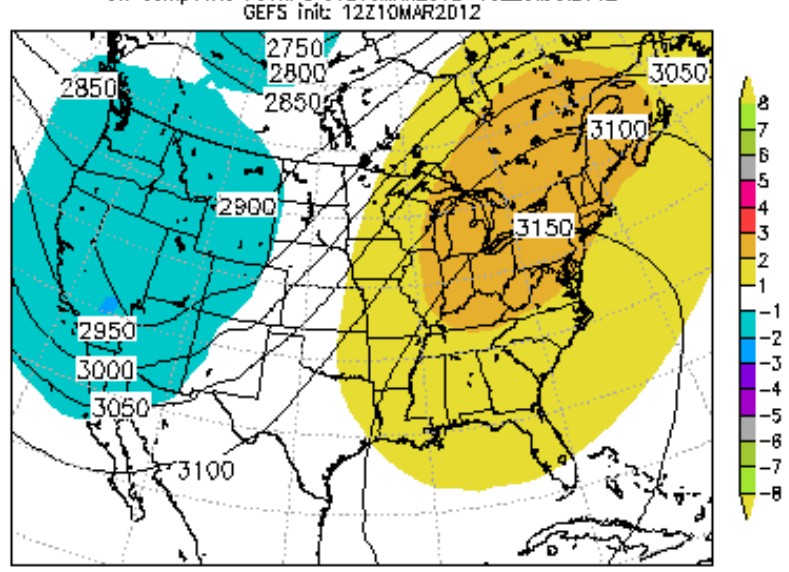

$2013-10-6 e-1031$

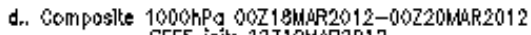

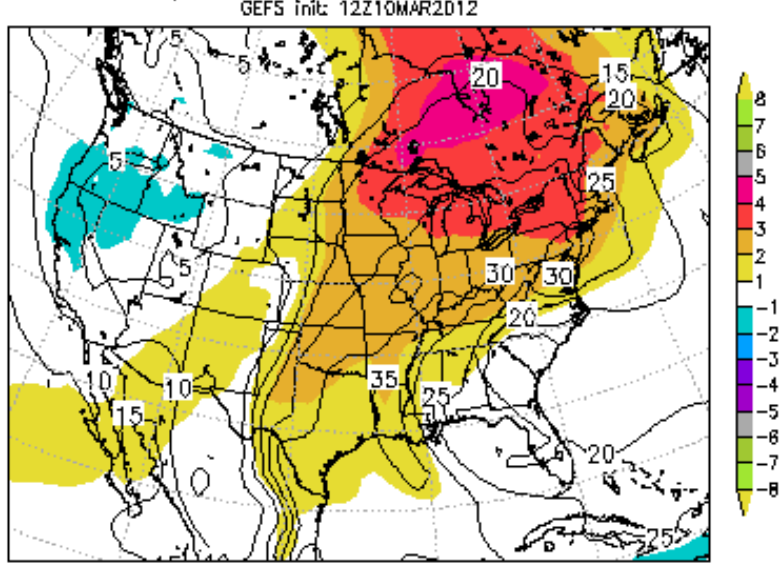

9004 mast

Figure 12. As in Fig. 11 except composited over the 48-h period of 0000 UTC 18 March to 20 March 2012.

occurring between the 14th and 21st. Furthermore, 4570 coldest-maximum temperature records were tied or broken, with 3988 occurring between the 14th and 21st. Normalizing these statistics for the period of record and number of stations, this represents $2 \%$ of the total possible United States low temperature records for the month (NCDC 2012a, Fig. 2), with the peak percentage reaching $15 \%$ of possible daily low temperature records on 19 January. The pattern characterizing the height of the event (14-21 January) is shown in Fig. 13. A highly amplified flow is shown with negative $500-\mathrm{hPa}$ height and $850-\mathrm{hPa}$ temperature anomalies around $-2 \sigma$ over the eastern half of North America. The standardized anomaly approach in assessing the potential for high-impact events, when used within proper historical context, can demonstrate the potential for anomalous warmth and cold, as well as other sensible-weather challenges including the potential for flooding rainfall.
Finally, this study found that the March 2012 event was highly predictable. Numerous forecasts preceding the event not only correctly anticipated the strength of meteorological fields, but also the breadth and persistence of the event. Standardized anomalies (cms.met.psu.edu/sref/ensembles/) were found to assist in determining this forecast consistency and, thus, should be considered as a valuable tool in forecasting anomalous events. The accuracy of forecasts for this event are not surprising given that the primary driver for the event was the anomalous eastern North American ridge. Numerical weather prediction models have increasing ability to forecast at the synoptic scale, which suggests that, when operational forecasters see such an event in deterministic and ensemble simulations, they can be confident that highly anomalous temperatures will occur and can therefore give advanced warning to decision makers. 

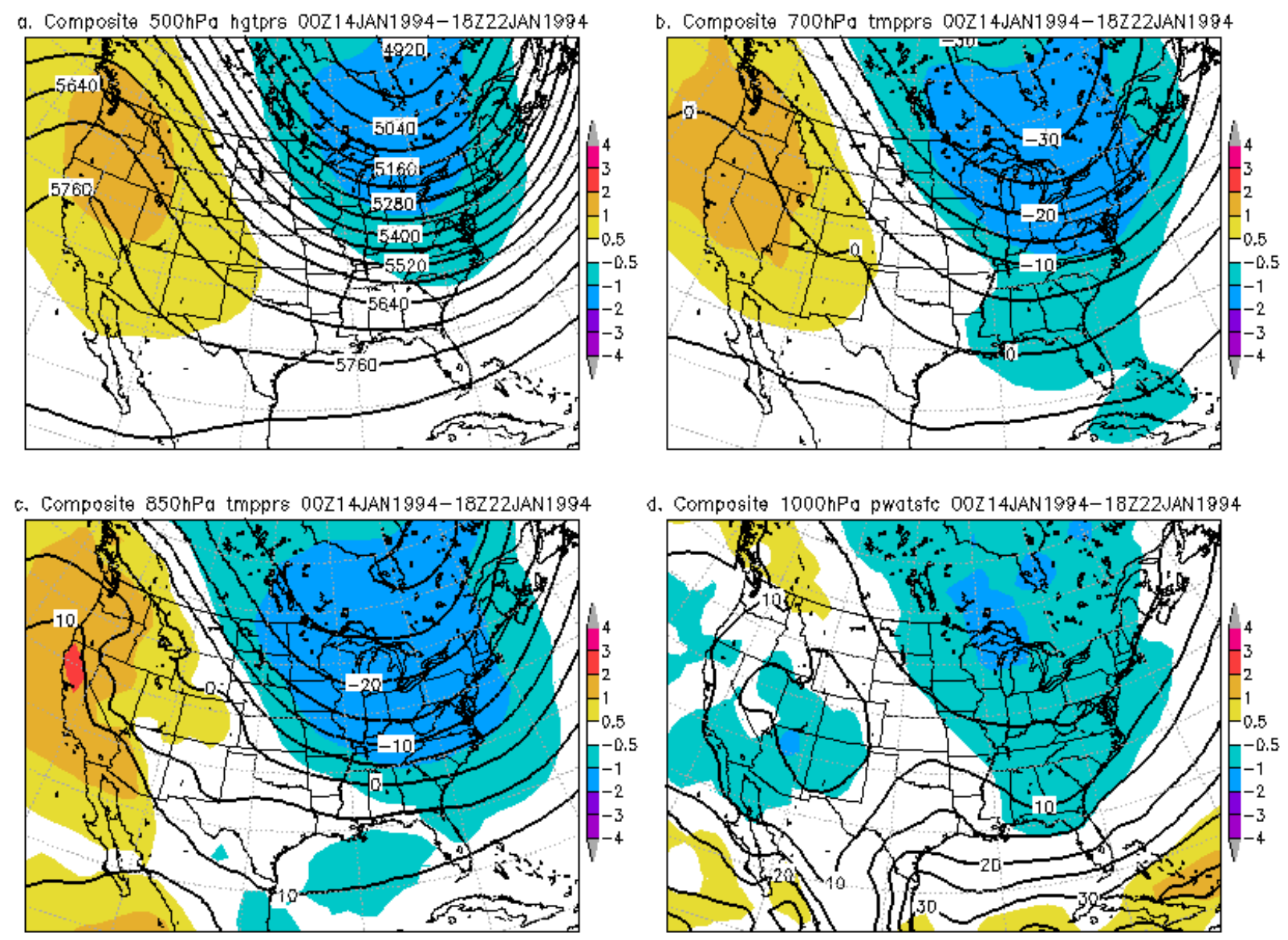

Figure 13. As in Fig. 3 except composited over the period from 0000 UTC 14 January through 1800 UTC 22 January 1994.

Acknowledgments. The authors acknowledge John LaCorte, a Senior Forecaster at the State College, PA, weather forecast office, for gathering some of the climatological data used in this study. Dave Radell at the Eastern Region Headquarters of the National Weather Service (NWS), as well as Jeffrey Manion at the Central Region Headquarters of the NWS, provided helpful reviews of the manuscript that improved its quality. The authors also thank Matt Bunkers, Randy Graham, and two anonymous reviewers for making substantial improvements to the manuscript.

\section{REFERENCES}

Brugge, R., 1995: Heatwaves and record temperatures in North America, June 1994. Weather, 50, 20-23, CrossRef.

Chang, F.-C., and J. M. Wallace, 1987: Meteorological conditions during heat waves and droughts in the United States Great Plains. Mon. Wea. Rev., 115, 12531269, CrossRef.
Changnon, S. A., K. E. Kunkel, and B. C. Reinke, 1996: Impacts and responses to the 1995 heat wave: A call to action. Bull. Amer. Meteor. Soc., 77, 1497-1506, CrossRef.

Church, V. H., 1913: Drought and heat wave of 1913 in Indiana. Mon. Wea. Rev., 41, 1455-1456, CrossRef.

Compo, G. P., and Coauthors, 2011: The Twentieth Century Reanalysis Project. Quart. J. Roy. Meteor. Soc., 137, 128, CrossRef.

Cramer, O. P., and R. E. Lynott, 1970: Mesoscale analysis of a heat wave in western Oregon. J. Appl. Meteor. 9, 740-759, CrossRef.

DeGaetano, A. T., T. J. Brown, S. D. Hilberg, K. Redmond, K. Robbins, P. Robinson, M. Shulski, and M. McGuirk, 2010: Toward regional climate services: The role of NOAA's regional climate centers. Bull. Amer. Meteor. Soc., 91, 1633-1644, CrossRef.

Flesher, J., cited 2012: Feds declare disaster over damaged fruit crops. Food Manufacturing, 3 July 2012. [Available online at www.foodmanufacturing.com/ news/2012/07/feds-declare-disaster-over-damagedfruit-crops.] 
Glickman, T. S., 2000: Glossary of Meteorology. Amer. Meteor. Soc., 855 pp.

Goklany, I., 2009: Deaths and death rates from extreme weather events: 1900-2008. J. Amer. Physicians and Surgeons, 14 (4), 102-109.

Grumm, R. H., 2011: The central European and Russian heat event of July-August 2010. Bull. Amer. Meteor. Soc., 92, 1285-1296, CrossRef.

Hart, R. E., and R. H. Grumm, 2001: Using normalized climatological anomalies to rank synoptic scale events objectively. Mon. Wea. Rev., 129, 2426-2442, CrossRef.

Kalnay, E., and Coauthors, 1996: The NCEP/NCAR 40year reanalysis project. Bull. Amer. Meteor. Soc., 77, 437-471, CrossRef.

Karl, T. R., 1986: The sensitivity of the Palmer Drought Severity Index and Palmer's Z-index to their calibration coefficients including potential evapotranspiration. $J$. Climate Appl. Meteor., 25, 77-86, CrossRef.

Kousky, V. E., 1985: The global climate for December 1984-February 1985: A case of strong intraseasonal oscillations. Mon. Wea. Rev., 113, 2158-2172, CrossRef.

Lin, Y., and K. E. Mitchell, 2005: The NCEP Stage II/IV hourly precipitation analyses: Development and applications. Preprints, 19th Conf. on Hydrology, San Diego, CA, Amer. Meteor. Soc., 1.2. [Available online at ams.confex.com/ams/pdfpapers/83847.pdf.]

Lipton, K., R. H. Grumm, R. Holmes, P. Knight, and J. Ross, 2005: Forecasting heat waves using climatic anomalies. Preprints, 21st Conf. on Weather Analysis and Forecasting/17th Conf. on Numerical Weather Prediction, Washington, D.C., Amer. Meteor. Soc., P1.60. [Available online at ams.confex.com/ams/ pdfpapers/94498.pdf.]

Livezey, R. E., 1981: Weather and circulation of November 1980: A late heat wave and hurricane and early snow. Mon. Wea. Rev., 109, 396-402, CrossRef.

Lyon, B., and R. M. Dole, 1995: A diagnostic comparison of the 1980 and 1988 U. S. summer heat wavedroughts. J. Climate, 8, 1658-1675, CrossRef.

Madden, R. A., and P. R. Julian, 1971: Description of a 4050 day oscillation in the zonal wind in the tropical Pacific. J. Atmos. Sci., 28, 702-708, CrossRef. , and _ 1972: Description of global-scale circulation cells in the tropics with a 40-50 day period. J. Atmos. Sci., 29, 1109-1123, CrossRef.

McQueen, H. R., and C. Pope Jr., 1957: The eastern states heat wave of April 20-28, 1957. Mon. Wea. Rev., 85, 132-139, CrossRef.

Met Office, cited 2014: Heatwave. [Available online at www.metoffice.gov.uk/learning/learn-about-theweather/weather-phenomena/heatwave.]

Mo, K. C., and R. W. Higgins, 1998a: Tropical convection and precipitation regimes in the western United States. J. Climate, 11, 2404-2423, CrossRef.
, and 1998b: Tropical influences on California precipitation. J. Climate, 11, 412-430, CrossRef.

Namias, J., 1982: Anatomy of Great Plains protracted heat waves (especially the 1980 U.S. summer drought). Mon. Wea. Rev., 110, 824-838, CrossRef.

NCDC, cited 2012a: Daily Weather Records. [Available online at www.ncdc.noaa.gov/extremes/records/.] , cited 2012b: Storm Events Database. [Available online at www.ncdc.noaa.gov/stormevents/.]

Neiman, P. J., F. M. Ralph, G. A. Wick, J. D. Lundquist, and M. D. Dettinger, 2008: Meteorological characteristics and overland precipitation impacts of atmospheric rivers affecting the West Coast of North America based on eight years of SSM/I satellite observations. J. Hydrometeor., 9, 22-47, CrossRef.

Nunn, R., 1927: The "January Thaw." Mon. Wea. Rev., 55, 20-21, CrossRef.

Palmer, T. N., C. Brankovic, F. Molteni, S. Tibaldi, L. Ferranti, A. Hollingsworth, U. Cubasch, and E. Klinker, 1990: The European Centre for Medium-Range Weather Forecasts (ECMWF) program on extendedrange prediction. Bull. Amer. Meteor. Soc., 71, 13171330, CrossRef.

Palmer, W. C., 1965: Meteorological drought. Research Paper 45, U.S. Dept. of Commerce, Washington, D.C., $65 \mathrm{pp}$. [Available online at www.ncdc.noaa.gov/tempand-precip/drought/docs/palmer.pdf.]

Ramde, D., and C. Antlfinger, cited 2012: Tart cherry crop in Midwest destroyed by weather. The Big Story, 13 July 2012. [Available online at bigstory.ap.org/article/ tart-cherry-crop-midwest-destroyed-weather.]

Robinson, P. J., 2001: On the definition of a heat wave. $J$. Appl. Meteor., 40, 762-775, CrossRef.

Stuart, N. A., R. H. Grumm, and M. J. Bodner, 2013: Analyzing predictability and communicating uncertainty: Lessons from the post-Groundhog Day 2009 storm and the March 2009 "megastorm." J. Operational Meteor., 1 (16), 185-199, CrossRef.

Tracton, M. S., K. Mo, W. Chen, E. Kalnay, R. Kistler, and G. White, 1989: Dynamical extended range forecasting (DERF) at the National Meteorological Center. Mon. Wea. Rev, 117, 1604-1635, CrossRef.

Wagner, A. J., 1976: Weather and circulation of April 1976: Unprecedented spring heat wave in the Northeast and record drought in the Southeast. Mon. Wea. Rev., 104, 975-982, CrossRef.

Wallace, J. M., and D. S. Gutzler, 1981: Teleconnections in the geopotential height field during the Northern Hemisphere winter. Mon. Wea. Rev., 109, 784-812, CrossRef.

Walsh, J. E., A. S. Phillips, D. H. Portis, and W. L. Chapman, 2001: Extreme cold outbreaks in the United States and Europe, 1948-99. J. Climate, 14, 26422658, CrossRef.

Weaver, S. J., and S. Nigam, 2008: Variability of the Great Plains low-level jet: Large-scale circulation context and 
hydroclimate impacts. J. Climate, 21, 1532-1551, CrossRef.

Wheeler, M. C., and H. H. Hendon, 2004: An all-season real-time multivariate $\mathrm{MJO}$ index: Development of an index for monitoring and prediction. Mon. Wea. Rev., 132, 1917-1932, CrossRef.
Zhou S., M. L'Heureux, S. Weaver, and A. Kumar, 2011: A composite study of the MJO influence on the surface air temperature and precipitation over the continental United States. Clim. Dyn., 38, 1459-1471, CrossRef. 